\title{
Effects of $\mathrm{ZnO}$, $\mathrm{TiO}_{2}$ or $\mathrm{Fe}_{2} \mathrm{O}_{3}$ Nanoparticles on the Body Mass, Reproduction, and Survival of Eisenia fetida
}

\author{
María Fernanda Valerio-Rodríguez ${ }^{1}$, Libia Iris Trejo-Téllez ${ }^{2}$, \\ Miguel Ángel Aguilar-González ${ }^{1}$, Gabriela Medina-Pérez ${ }^{3}$, \\ Juan Carlos Zúñiga-Enríquez ${ }^{4}$, Adolfo Ortegón-Pérez ${ }^{4}$, \\ Fabián Fernández-Luqueño ${ }^{1 *}$
}

\author{
${ }^{1}$ Sustainability of Natural Resources and Energy Program, Cinvestav-Saltillo, Coahuila, Mexico \\ ${ }^{2}$ Colegio de Postgraduados, Campus Montecillo, Carretera Mexico-Texcoco, Mexico \\ ${ }^{3}$ Transdisciplinary Doctoral Program in Scientific and Technological Development for Society, Cinvestav, \\ Zacatenco, Mexico City, Mexico \\ ${ }^{4}$ Universidad Autónoma Agraria Antonio Narro, Saltillo, Coahuila, Mexico
}

Received: 30 November 2017

Accepted: 11 December 2018

\begin{abstract}
The increasing production of nanoparticles and its byproducts bring as a priority the necessity of understanding the interaction between earthworms and nanoparticles (NPs) in an agricultural soil. The present study addresses the effects of $\mathrm{ZnO}-, \mathrm{TiO}_{2}-$ or $\mathrm{Fe}_{2} \mathrm{O}_{3}-\mathrm{NPs}$ in the body mass change, reproduction and survival of Eisenia fetida. Earthworms were exposed to increasing concentrations of each NPs $(0.0,0.15$ and $0.3 \mathrm{~g}$ NPs kg-1 dry soil, in an amended soil while total and bioavailable $\mathrm{Zn}$, Ti and Fe were monitored in an aerobic incubation experiment of 60 days. Earthworms exposed to $0.15 \mathrm{~g} \mathrm{TiO}_{2}-\mathrm{NPs}$ kg-1 dry soil and 0.3 g ZnO-NPs kg-1 dry soil did not lead to adults' deaths. However, when soil was amended with $0.15 \mathrm{~g} \mathrm{Fe}_{2} \mathrm{O}_{3}$-NPs kg-1 dry soil the survival decreased significantly compared with the control treatment. Cocoon production was not significantly different between treatments, suggesting that NPs have no effect on earthworm reproduction. ZnO-NPs at $0.3 \mathrm{~g} \mathrm{kg-1}$ dry soil enhanced juveniles on growing and survival. Although bioaccumulation of Ti in earthworm biomass was not statically different in treatments spiked with $\mathrm{TiO}_{2}-\mathrm{NPs}$, there were significant differences between treatments amended with different doses of $\mathrm{ZnO}$ - and $\mathrm{Fe}_{2} \mathrm{O}_{3}$-NPs, showing that bioaccumulation of $\mathrm{Zn}$ and $\mathrm{Fe}$ in earthworms increases on par with dose. Meanwhile, the Fe bioaccumulation was significantly lower in earthworms exposed to $\mathrm{Fe}_{2} \mathrm{O}_{3}$-NPs than those in the control group.
\end{abstract}

Keywords: earthworms, environmental pollution, nanotechnology, soil degradation, soil microbiota

*e-mail: cinves.cp.cha.luqueno@gmail.com 


\section{Introduction}

The manufactured nanomaterials (MNMs), which are materials with at least one dimension between 1 and $100 \mathrm{~nm}$, have found a wide scope in agriculture, energy generation, electronics, drug administration and medical diagnostics [1]. In the agricultural sector, MNMs such as organic or inorganic nanoparticles (NPs) have been used to reduce the damage from pests and diseases, increase crop yields, drought tolerance, and the nutritional contents of fruits, but also to extend the shelf life of food or to produce slow-release fertilizers [2-4].

Nanoparticles (NPs) are universally used in many products commonly employed by humans, such as food, clothing, medicines and cleaning products. In some cases, the NPs are made of materials with known toxicity; however, their properties may differ from their counterparts of higher mass, inducing additional biological activity in their smaller size, greater surface area and reactivity, which means that there is real potential in the NPs to exhibit toxic effects. Nanotechnology will be the center of science, technology and business for the coming years, so due to the expected increase in MNM production, government agencies and scientists have begun to investigate the environmental fate and behavior of these materials in order to understand the potential risks to humans and other organisms that are exposed to NPs [5-7].

The widespread application of MNMs makes inevitable that NPs get discharged into the environment intentionally or accidentally, while most MNMs discharged into the wastewater stream are distributed to activated sludge. Therefore, agricultural soils might serve as a sink for a significant fraction of the MNMs released to the environment through the soil when activated sludge is poured into farm fields to improve soil fertility or during the atmospheric deposition of NPs [1, 8, 9]. However, despite the large amount of research conducted about the potential applications of nanotechnology in recent years, relatively little has been done to assess the potential risks of NPs for the environment, particularly in earthworms [1, 5, 7]. Stewart et al. [5] stated that the chemical modification of cadmium selenide quantum dots protected to Eisenia andrei and reduced the bioaccumulation of NPs by earthworms. Other experiments regarding the nanotoxicity of NPs on E. andrei was carried out by Romero-Freire et al. [7]. They reported that survival, weight change, and reproduction were affected by both $\mathrm{Zn}$-NPs or $\mathrm{ZnCl}_{2}$, but they could not explain the differences in earthworm toxicity. Similar studies were made by Swiatek et al. [10] to evaluate the effect of $\mathrm{Zn}$ NPs or $\mathrm{ZnCl}_{2}$ on reproduction of $E$. Andrei, but zinc was efficiently regulated by the earthworms in all treatments.

Enchytraeus crypticus has also been studied to determine the toxicity of $\mathrm{ZnO}$-NPs to the annelids [11]. They found that the toxicity was clearly dependent on the size of $\mathrm{ZnO}-\mathrm{NP}$ agglomerates and the technique of exposure media preparation, but it was not correlated with ZnO-NP concentrations. The survival and the composition of gut micloflora of E. fetida grown in a soil polluted with Zn-NPs has also been analyzed [13]. They reported that Zn-NPs decreased the diversity of bacteria belonging to the taxon Firmicutes and increased the proportion of proteobacteria.

The ecotoxicology of NPs has so far been studied using bacteria and aquatic species [12]. However, research work to address the effects on soil dwelling invertebrates is in a preliminary stage, but studies on scale mealybugs, earthworms and nematodes are beginning to emerge $[1,5,7,10]$. Preliminary results of soil species have revealed the diverse nature of the responses to the different types of NPs [5, 7, 10-13]. E. fetida was selected as a model organism for this study due to it being an important species in toxicity testing of soils, as standardized by the Organization for Economic Cooperation and Development [14], the Department of Ecology of Washington State University [15], and the Environmental Technology Centre of Canada [16].

Table 1. Main characteristics of nanoparticles used in this research.

\begin{tabular}{|c|c|c|c|}
\hline \multirow{2}{*}{ Characteristics } & \multicolumn{2}{|c|}{ Nanoparticles } \\
\cline { 2 - 4 } & Hematite & Zinc Oxide & Titanium Dioxide \\
\hline Chemical formula & $\alpha-\mathrm{Fe}_{2} \mathrm{O}_{3}$ & ZnO & White \\
\hline Color & Red ochre & White & 4.23 \\
\hline Density $\left(\mathrm{g} \mathrm{cm}^{-3}\right)$ & 5.42 & 5.61 & 79.87 \\
\hline Molecular weight $(\mathrm{Da})$ & 159.69 & 81.40 & 1843 \\
\hline Melting point $\left({ }^{\circ} \mathrm{C}\right)$ & 1565 & 1975 & Anatase \\
\hline Crystalline phase & hematite & Wurtzite & $50-100$ \\
\hline Particle size $(\mathrm{nm})$ & 80 a 94 & Te-100 & Hexagonal \\
\hline Crystallographic system & Hexagonal & Weakly ferromagnetic & Weakly ferromagnetic \\
\hline Magnetic properties & Weakly antiferromagnetic & & \\
\hline
\end{tabular}


a) X-ray diffraction patterns
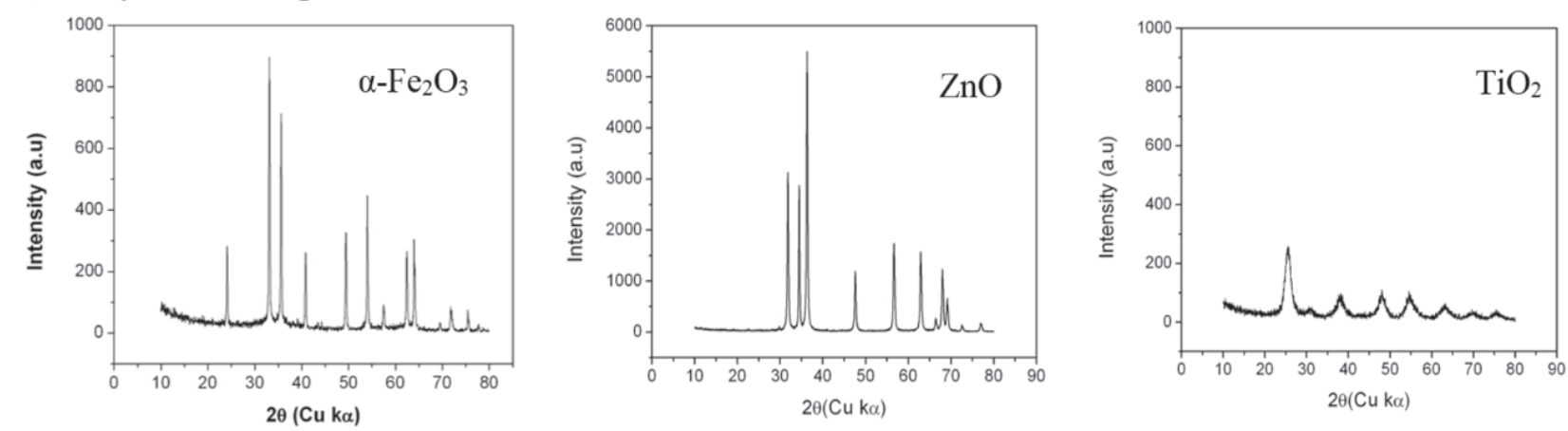

b) Magnetization curves
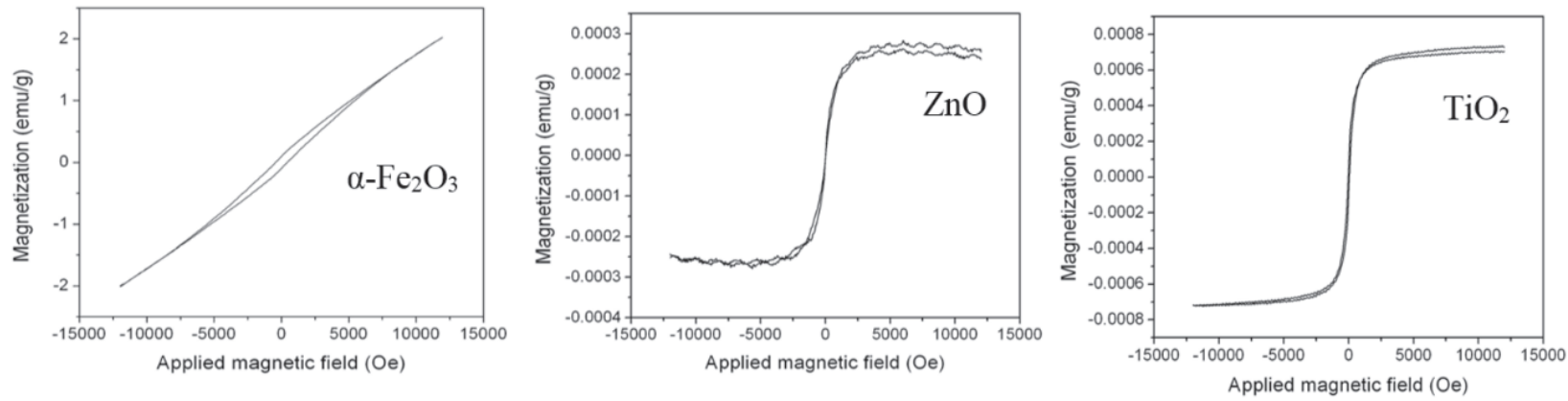

Fig. 1. X-ray diffraction patterns a) and Magnetization curves b) of hematite $\left(\alpha-\mathrm{Fe}_{2} \mathrm{O}_{3}\right)$, zinc oxide $(\mathrm{ZnO})$, or titanium dioxide (TiO $)$ nanoparticles

Besides being a species that plays an important role in terrestrial ecosystems, as it not only plays a critical role in biogeochemical cycles and the function of soils, it is also a common prey for a large number of consumers at high levels in the food chain.

The present study aims to demonstrate the effects of three varieties of NPs - hematite $\left(\mathrm{Fe}_{2} \mathrm{O}_{3}\right)$, zinc oxide $(\mathrm{ZnO})$ and titanium dioxide $\left(\mathrm{TiO}_{2}\right)$ - on the change in body mass and the survival and reproduction of the worm E. fetida.

\section{Material and Methods}

\section{Nanoparticle Characterization}

Nanoparticles of hematite $\left(\alpha-\mathrm{Fe}_{2} \mathrm{O}_{3}\right)$, zinc oxide $(\mathrm{ZnO})$, and titanium dioxide $\left(\mathrm{TiO}_{2}\right)$ were purchased from Investigación y Desarrollo de Nanomateriales S.A. de C.V. The main characteristics of these NPs are listed in Table 1. The composition of the NPs was determined by analysis of X-ray diffraction (XRD) with Philips X'Pert diffraction equipment based Cu-ka (Fig. 1). The magnetic properties of NPs were measured with an alternating gradient magnetometer (AGM Micromag 2900) manufactured by Princeton Measurements Corporation (Fig. 1). The morphology of the samples was obtained by Transmission Electron Microscopy (TEM), with a Tecnai F30 HRTEM manufactured by FEI (Fig. 2) and by scanning electron microscopy (SEM) with a Dual Beam FEI team Nova200 Nanolab manufactured by FEI (Fig. 2).

\section{Area Description and Soil Sampling}

This study was carried out under plant growth chamber conditions by Sustainability of Natural Resources and Energy Program at CINVESTAV-Saltillo in Saltillo, Coahuila, Mexico. Additionally, according to the FAO/UNESCO soil classification system, the soil is a Haplic Xerosol with $\mathrm{pH} 7.3$, electrolytic conductivity of $4.8 \mathrm{dS} \mathrm{m} \mathrm{m}^{-1}$, water-holding capacity (WHC) of $865 \mathrm{~g} \mathrm{~kg}^{-1}$, organic carbon content of $1.5 \mathrm{~g} \mathrm{C} \mathrm{kg}^{-1}$ soil, and a total $\mathrm{N}$ content of $0.7 \mathrm{~g} \mathrm{~N} \mathrm{~kg}^{-1}$ soil (Table 2). Soil was sampled at random by augering the $0-15 \mathrm{~cm}$ top-layer of three plots of approximately 0.5 ha. The soil from each plot was pooled so that three soil samples were obtained. The experimental setup was carried out from November 2015 to February 2016.

\section{Soil Preparation}

The soil was taken to the laboratory and treated as follows. The soil from each plot was passed separately through a five $\mathrm{mm}$ sieve, adjusted to $40 \%$ WHC by adding distilled water $\left(\mathrm{H}_{2} \mathrm{O}\right)$ and conditioned at $22 \pm 2^{\circ} \mathrm{C}$ for 10 days in drums containing a beaker with $100 \mathrm{ml}$ $1 \mathrm{M}$ sodium hydroxide $(\mathrm{NaOH})$ to trap evolved $\mathrm{CO}_{2}$, 

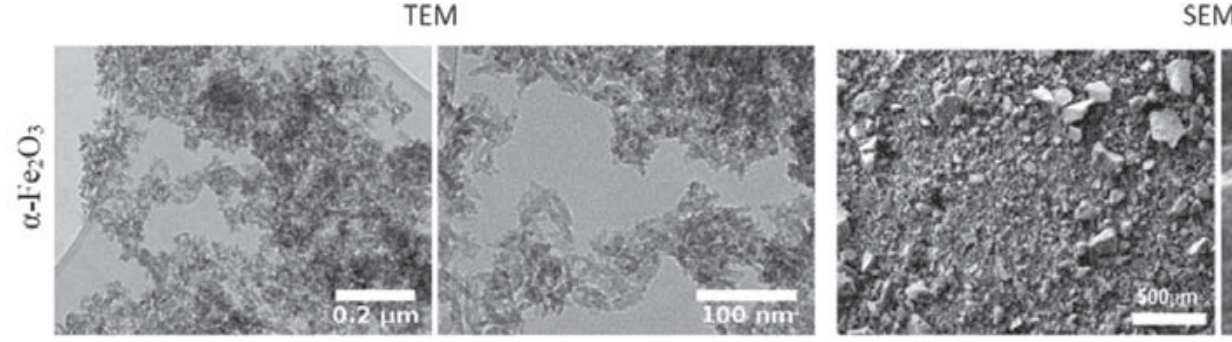

SEM
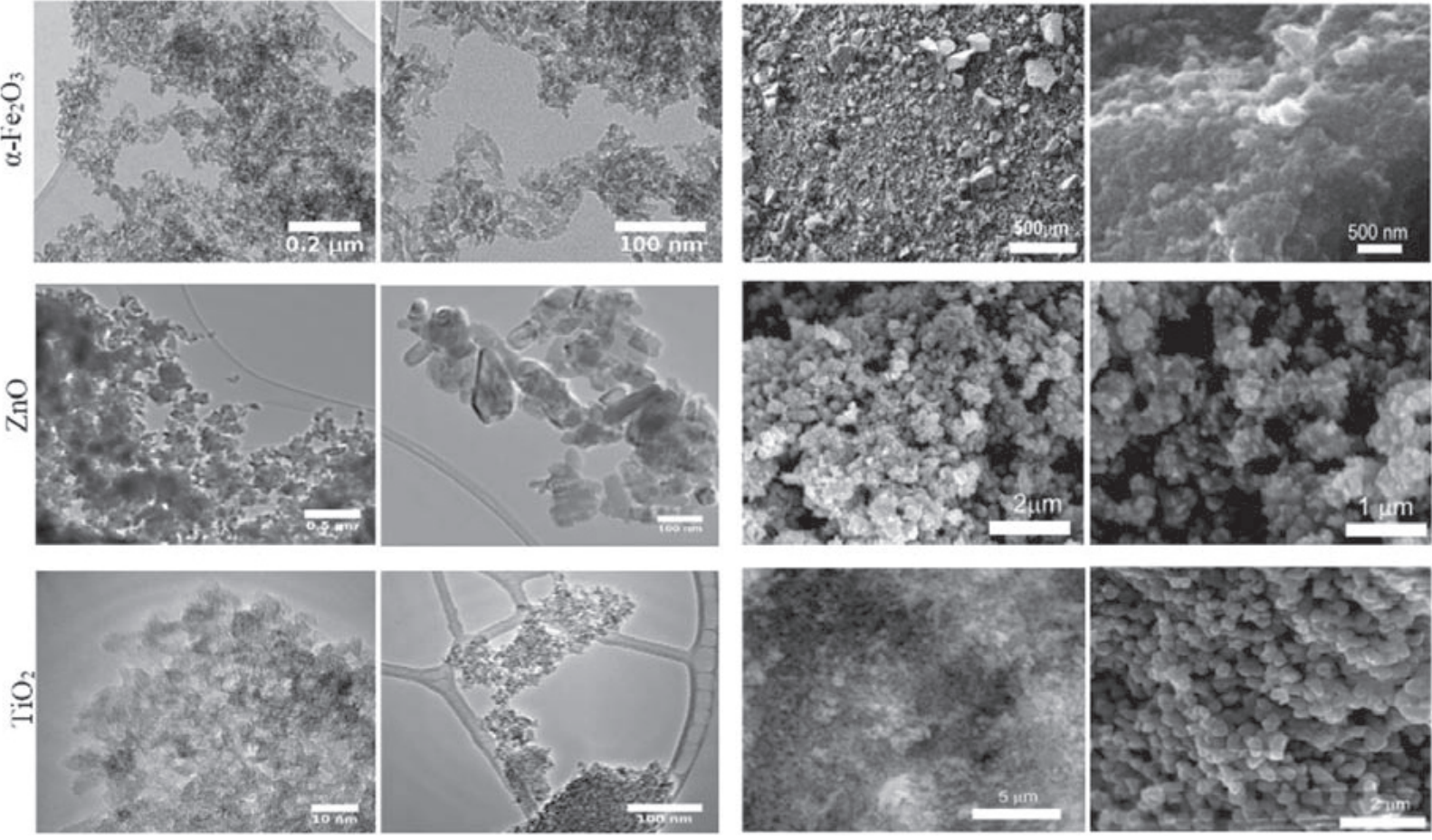

titanium dioxide $\left(\mathrm{TiO}_{2}\right)$ nanoparticles.

and a beaker with $100 \mathrm{ml}$ distilled $\mathrm{H}_{2} \mathrm{O}$ to avoid desiccation of the soil. After this process the soil was tyndallized to remove any organisms that could be harmful to the earthworms.

\section{Vermicompost Preparation}

Vermicompost used to feed the earthworms were obtained from the worm culture maintained in our facilities, which is kept based on pre-composted organic material bedding. The pre-composting process was carried out in plastic composters and was allowed to stand for 30 days. Once realized, the pre-composting organic material was added to the bedding, and after one month the amount of vermicompost used to supply food to the experimental units was removed (Table 2). Thereafter, the material obtained was tyndallized to remove any organisms that could be harmful to the earthworms.

\section{Eisenia fetida Culture}

All earthworms used in the present study came from a culture of Eisenia fetida maintained in our facility. The culture is kept in a bedding of pre-composted organic kitchen waste.

\section{Experimental Set-up}

One hundred and sixty eight sub-samples of 200 g dry soil (i.e., 14 treatments $\times$ three replicates $\times$ four destructive samples date: 0, 20, 40 and 60 days after the onset of the experiment) were added to amber glass jars of $900 \mathrm{ml}$ (length $18 \mathrm{~cm}$ and $\varnothing 10 \mathrm{~cm}$ ). $\alpha-\mathrm{Fe}_{2} \mathrm{O}_{3}-, \mathrm{ZnO}-$, or $\mathrm{TiO}_{2}-\mathrm{NPs}$ were applied to the soil at three increasing concentrations $(0.0,0.15$ and $0.3 \mathrm{~g} \mathrm{~kg}$ dry soil $\left.{ }^{-1}\right)$ so six chemical suspensions of nanoparticles (three NPs types $\times$ two concentrations) prepared in distilled water, and they were sonicated during 30 minutes before use; after sonication the NP suspensions were added to the earthworm food (vermicompost or Quaker oats) and after the food was added it was completely mixed with the soil. Each amber glass jar was sealed with a mosquito net to avoid anaerobicity, stop the flying pests or avoid the earthworms from escaping. The experiment was carried out under plant growth chamber conditions, the average temperature was $22 \pm 2^{\circ} \mathrm{C}$ and the photoperiod was 12 hours light and 12 hours dark. In a completely randomized design, each experimental unit was prepared, incubated, and sampled independently. Ten Eisenia fetida earthworms with fully developed clitella and average fresh mass of $0.42 \mathrm{~g}$ were used in each experimental unit of this research. At the onset of the experiment, $35 \mathrm{~g}$ of dry vermicompost was added to each amber glass jar to feed the earthworms. Additionally, thirty and 50 days after the onset of the experiment, $35 \mathrm{~g}$ of tyndallized Quaker oats were added to feed the earthworms. Fourteen treatments were applied to the soil (Table 3). The aerobic incubation experiment lasted 60 days, in which four destructive and random samplings were performed on days 0,20 , 
Table 2. Characteristics of soil and vermicompost.

\begin{tabular}{|c|c|c|}
\hline Characteristic & Soil & Vermicompost \\
\hline $\mathrm{pH}_{\mathrm{H}_{2} \mathrm{O}}$ & 7.3 & 6.8 \\
\hline Water holding capacity $\left(\mathrm{g} \mathrm{kg}^{-1}\right)^{\text {a }}$ & 865 & $\mathrm{ND}^{\mathrm{b}}$ \\
\hline Water content $\left(\mathrm{g} \mathrm{kg}^{-1}\right)$ & 120 & 90 \\
\hline Total Organic carbon $\left(\mathrm{g} \mathrm{kg}^{-1}\right)$ & 1.5 & 426 \\
\hline Inorganic carbon $\left(\mathrm{g} \mathrm{kg}^{-1}\right)$ & 0.4 & 0.0 \\
\hline Total Kjeldahl nitrogen $\left(\mathrm{g} \mathrm{kg}^{-1}\right)$ & 0.7 & 21.2 \\
\hline $\mathrm{N}^{-\mathrm{NH}_{4}^{+}}\left(\mathrm{mg} \mathrm{kg}^{-1}\right)$ & 4.2 & ND \\
\hline $\mathrm{N}-\mathrm{NO}_{3}^{-}\left(\mathrm{mg} \mathrm{kg}^{-1}\right)$ & 69 & ND \\
\hline $\mathrm{N}-\mathrm{NO}_{2}^{-}\left(\mathrm{mg} \mathrm{kg}^{-1}\right)$ & 0.1 & ND \\
\hline $\begin{array}{l}\text { Humics substances carbon ( } \mathrm{g} \\
\qquad \mathrm{kg}^{-1} \text { ) }\end{array}$ & ND & 64.2 \\
\hline Humics acids carbon $\left(\mathrm{g} \mathrm{kg}^{-1}\right)$ & ND & 32.1 \\
\hline Fulvic acids carbon $\left(\mathrm{g} \mathrm{kg}^{-1}\right)$ & ND & 34.2 \\
\hline Water soluble carbon $\left(\mathrm{g} \mathrm{kg}^{-1}\right)$ & ND & 6.1 \\
\hline $\mathrm{C} / \mathrm{N}$ ratio & 2.1 & 7.2 \\
\hline Total phosphorus $\left(\mathrm{g} \mathrm{kg}^{-1}\right)$ & 0.5 & ND \\
\hline Extractable phosphorus ( $\left.\mathrm{mg} \mathrm{kg}^{-1}\right)$ & 2.1 & ND \\
\hline $\mathrm{Ca}\left(\mathrm{mg} \mathrm{kg}^{-1}\right)$ & 1200 & 52000 \\
\hline $\operatorname{Mg}\left(\mathrm{mg} \mathrm{kg}^{-1}\right)$ & 52 & 6000 \\
\hline $\mathrm{K}\left(\mathrm{mg} \mathrm{kg}^{-1}\right)$ & 85 & 28000 \\
\hline $\mathrm{Fe}\left(\mathrm{mg} \mathrm{kg}^{-1}\right)$ & 22.2 & 525 \\
\hline $\mathrm{Cu}\left(\mathrm{mg} \mathrm{kg}^{-1}\right)$ & 0.8 & 51 \\
\hline $\mathrm{Zn}\left(\mathrm{mg} \mathrm{kg}^{-1}\right)$ & 0.6 & 725 \\
\hline $\operatorname{Mn}\left(\mathrm{mg} \mathrm{kg}^{-1}\right)$ & 19.2 & 240 \\
\hline Electrolytic conductivity $\left(\mathrm{dS} \mathrm{m}^{-1}\right)$ & 4.8 & 2.1 \\
\hline Clay content $\left(\mathrm{g} \mathrm{kg}^{-1} \mathrm{l}\right)$ & 14.2 & ND \\
\hline Silt content $\left(\mathrm{g} \mathrm{kg}^{-1}\right)$ & 40.4 & ND \\
\hline Sand content $\left(\mathrm{g} \mathrm{kg}^{-1}\right)$ & 45.4 & ND \\
\hline Textural soil classification & Loam & ND \\
\hline Bulk density $\left(\mathrm{g} \mathrm{kg}^{-1}\right)$ & 1.2 & 0.28 \\
\hline
\end{tabular}

${ }^{\mathrm{a}}$ On a dry base, ${ }^{\mathrm{b}}$ Not determined.

40 and 60. During each sampling day adult earthworms, cocoons and juveniles were hand-sorted and counted.

In addition, 70 sub-samples of $200 \mathrm{~g}$ dry soil (i.e., seven treatments: six treatments which contain earthworms + the control treatment) $\times$ two replicates $\times$ five destructive samples date $(0,7,14,40$, and 60 days after the onset of the experiment) were added to amber glass jars of $900 \mathrm{ml}$ (length $18 \mathrm{~cm}$ and $\varnothing 10 \mathrm{~cm}$ ). These experimental units were carried out in order to take up two earthworms per jar at $0,7,14,40$, and $60 \mathrm{~d}$ to take their picture. Once the earthworms were taken up, they were washed and hydrated by distilled water in a Petri dish until photographed. Additionally, earthworms were rinsed with deionized water, blotted dry with filter paper and weighed to check for possible body mass changes. Later earthworms were starved individually on moist filter paper in plastic containers with perforated lids for $48 \mathrm{~h}$ to ensure soil removal from the gut. The filter papers were changed after 24 and $36 \mathrm{~h}$ to minimize coprophagy. After that, adult earthworms were frozen at $-20^{\circ} \mathrm{C}$ until laboratory analysis. The first experiment ran from the 1 August until the 27 September 2015, while the second experiment ran from 3 February until the 3 April 2016.

Chemical Characterization of Soil and Vermicompost, and Biochemical Analyses

Methodologies for chemical analysis of soil, vermicompost, and earthworms may be found in [17-18].

\section{Data Analysis and Statistical Methods}

Methodologies for statistical analysis may also be found in [17-18]. Briefly, the data were subjected to analysis of variance (ANOVA) using the software SAS 9.1 for windows, based on the least significant difference using the general linear model procedure (PROC GLM), and means were compared with the Tukey test $(\mathrm{P} \leq 0.05)$. All data presented were the mean of three replicates $\times$ four destructive sample dates $(0,20,40$ and 60 days after the onset of the experiment) $\times$ two consecutive experiments carried out in a plant growth chamber $(\mathrm{n}=24)$.

\section{Results}

\section{Physical Effects}

Seven days after the onset of the experiment, we observed that earthworms exposed to soils amended with 0.15 or $0.3 \mathrm{~g} \mathrm{Fe}_{2} \mathrm{O}_{3}$-NPs $\mathrm{Kg}$ dry soil ${ }^{-1}$ attempted to go out of the amber glass jar. Additionally, physical damage was detected in earthworms exposed to increasing doses of $\mathrm{Fe}_{2} \mathrm{O}_{3}$-NPs. The main detected damage was inflammation and explosion in certain areas of the earthworm's body (Figs $3 \mathrm{~b}$ and $3 \mathrm{~d}$ ), while the exposure of earthworms to other NPs did not cause obvious physical damage at 7 days (Figs 3b, 3g, 3l, 3q, and $3 \mathrm{w})$.

At 14 days, earthworms from soil amended with 0.15 or $0.3 \mathrm{~g} \mathrm{Fe}_{2} \mathrm{O}_{3}$-NPs $\mathrm{Kg}$ dry soil-1 ${ }^{-1}$ showed little mobility and impaired physical appearance (with partitions and ulcerations; pictures not shown), while the earthworms of the CONTROL treatment looked healthy as witnessed by their excellent mobility and color. Earthworms from

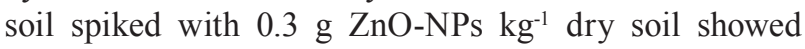


Table 3. Treatments applied to agricultural soil amended with increasing concentrations of nanoparticles ( $\mathrm{NPs}$ ) of $\alpha-\mathrm{Fe}_{2} \mathrm{O}_{3}, \mathrm{ZnO}$, or TiO ${ }_{2}$, and with or without earthworms; the aerobic incubation experiment lasted 60 days, in which four destructive and random samplings were performed on days $0,20,40$ and 60 .

\begin{tabular}{|c|c|}
\hline Treatment & Characteristics \\
\hline Fe-LOW-EW & Soil $^{\mathrm{a}}+$ vermicompost $^{\mathrm{b}}+0.15 \mathrm{~g} \mathrm{Fe}_{2} \mathrm{O}_{3}-\mathrm{NPs}^{\mathrm{c}}+$ earthworms $^{\mathrm{d}}$ \\
\hline Fe-HIGH-EW & Soil + vermicompost $+0.30 \mathrm{~g} \mathrm{Fe}_{2} \mathrm{O}_{3}$-NPs + earthworms \\
\hline Zn-LOW-EW & Soil + vermicompost $+0.15 \mathrm{~g}$ ZnO-NPs + earthworms \\
\hline Zn-HIGH-EW & Soil + vermicompost $+0.30 \mathrm{~g}$ ZnO-NPs + earthworms \\
\hline Ti-LOW-EW & Soil + vermicompost $+0.15 \mathrm{~g} \mathrm{TiO}_{2}-\mathrm{NPs}+$ earthworms \\
\hline Ti-HIGH-EW & Soil + vermicompost $+0.30 \mathrm{~g} \mathrm{TiO}_{2}-\mathrm{NPs}+$ earthworms \\
\hline Fe-LOW & $\mathrm{Soil}+$ vermicompost $+0.15 \mathrm{~g} \mathrm{Fe}_{2} \mathrm{O}_{3}-\mathrm{NPs}$ \\
\hline Fe-HIGH & Soil + vermicompost $+0.30 \mathrm{~g} \mathrm{Fe}_{2} \mathrm{O}_{3}$-NPs \\
\hline Zn-LOW & Soil + vermicompost $+0.15 \mathrm{~g}$ ZnO-NPs \\
\hline Zn-HIGH & Soil + vermicompost $+0.30 \mathrm{~g} \mathrm{ZnO}-\mathrm{NPs}$ \\
\hline Ti-LOW & Soil + vermicompost $+0.15 \mathrm{~g} \mathrm{TiO}_{2}-\mathrm{NPs}$ \\
\hline Ti-HIGH & Soil + vermicompost $+0.30 \mathrm{~g} \mathrm{TiO}_{2}-\mathrm{NPs}$ \\
\hline CONTROL & Soil + vermicompost + earthworms \\
\hline SOIL-VERMI & Soil + vermicompost \\
\hline
\end{tabular}

a $200 \mathrm{~g}$ dry soil, ${ }^{\text {b }} 35 \mathrm{~g}$ dry vermicompost; organic kitchen wastes were pre-composted by 30 days then vermicomposted by 30 days, tyndallized, and dried to air-dry condition; ${ }^{\mathrm{c}}$ per $\mathrm{kg}^{-1}$ dry soil; ${ }^{\mathrm{d}} 10$ Eisenia fetida earthworms with fully developed clitella and average fresh mass of $0.4 \mathrm{~g}$

a large, long and very prominent clitella (Fig. 3x). However, earthworms of the Zn-LOW-EW treatment showed that while the earthworms had excellent mobility and color, they looked very thin and small (Fig. 3r). Earthworms from soil treated with 0.15 or $0.3 \mathrm{~g} \mathrm{TiO}_{2}$-NPs $\mathrm{kg}^{-1}$ dry soil looked thin and lethargic (Figs $3 \mathrm{~h}$ and $3 \mathrm{~m}$ ).

Forty days after the onset of the experiment, earthworms of the CONTROL treatment had no visible physical changes. However, the few survivors from soil spiked with 0.15 or $0.3 \mathrm{~g} \mathrm{Fe}_{2} \mathrm{O}_{3}-\mathrm{NPs} \mathrm{Kg}$ dry soil ${ }^{-1}$ looked very lethargic, and unresponsive to stimuli of touch and light. Notwithstanding, in the Zn-LOW-EW and $\mathrm{Zn}-\mathrm{HIGH}-\mathrm{EW}$ treatments all individuals showed excellent mobility state (Fig. 3x), but earthworms from soil amended with $0.15 \mathrm{~g} \mathrm{ZnO-NPs} \mathrm{kg} \mathrm{dry} \mathrm{soil}{ }^{-1}$ looked quite thin, with low mobility and had smaller partitions (Fig. 3s). Additionally, earthworms from soil amended with 0.15 or $0.3 \mathrm{~g} \mathrm{TiO}_{2}$-NPs $\mathrm{Kg}$ dry soil ${ }^{-1}$ looked visibly thin (Figs. 3i and 3n).

At 60 days, earthworms from unamended soil had excellent mobility (Fig. 3e), while the few survivors of soil spiked with 0.15 or $0.3 \mathrm{~g} \mathrm{Fe}_{2} \mathrm{O}_{3}-\mathrm{NPs} \mathrm{Kg}$ dry soil ${ }^{-1}$ were too lethargic. Earthworms from soil amended with

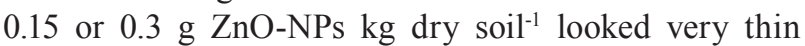
but had excellent mobility (Figs 3t and 3z). However, earthworms from soil amended with 0.15 or $0.3 \mathrm{~g}$ $\mathrm{TiO}_{2}$-NPs kg dry soil-1 looked thin, slow and some of them stumpy (Figs 3j and 3o).

\section{Biological Effects}

At the onset of the experiment the average earthworm body weight of each experimental unit (i.e., 10 earthworms of each amber glass jar) was not significantly different (Fig. 4a). Soil amended with $0.15 \mathrm{~g} \mathrm{TiO}_{2}$-NPs kg dry soil-1 or $0.3 \mathrm{~g} \mathrm{ZnO-NPs} \mathrm{kg}$ dry soil $^{-1}$ did not significantly change $(\mathrm{P}<0.05)$ the survival of adults earthworms compared to the CONTROL treatment (Fig. 4b). However, when soil was amended with hematite, the survival of adult earthworms significantly decreased $(\mathrm{P}<0.05)$ compared with the CONTROL treatment, suggesting that $\mathrm{Fe}_{2} \mathrm{O}_{3}$-NPs are harmful for adult earthworms (Fig. 4b). We found that soil spiked with $\mathrm{TiO}_{2}-\mathrm{NPs}$, $0.15 \mathrm{~g} \mathrm{ZnO}-\mathrm{NPs} \mathrm{kg}$ dry soil or $\mathrm{Fe}_{2} \mathrm{O}_{3}$-NPs significantly decreased juvenile growth and survival, compared with the CONTROL treatment (Fig. 4c). Additionally, earthworms grown with $\mathrm{TiO}_{2}$ - and $\mathrm{Fe}_{2} \mathrm{O}_{3}$-NPs or with $0.15 \mathrm{~g} \mathrm{ZnO}-\mathrm{NPs} \mathrm{kg}$ dry soil significantly decreased its weight at 60 days compared with the CONTROL treatment (Fig. 4d).

Cocoon production was inhibited in soils amended with $\mathrm{TiO}_{2}$ - and $\mathrm{Fe}_{2} \mathrm{O}_{3}$-NPs, while the soil amended with ZnO-NPs significantly increased the cocoon production compared with the other treatments, but not with the CONTROL treatment (Fig. 4e). However, the body mass did not change significantly when earthworms were grown in soil amended with $0.15 \mathrm{~g} \mathrm{TiO}_{2}-\mathrm{NPs}$ or 


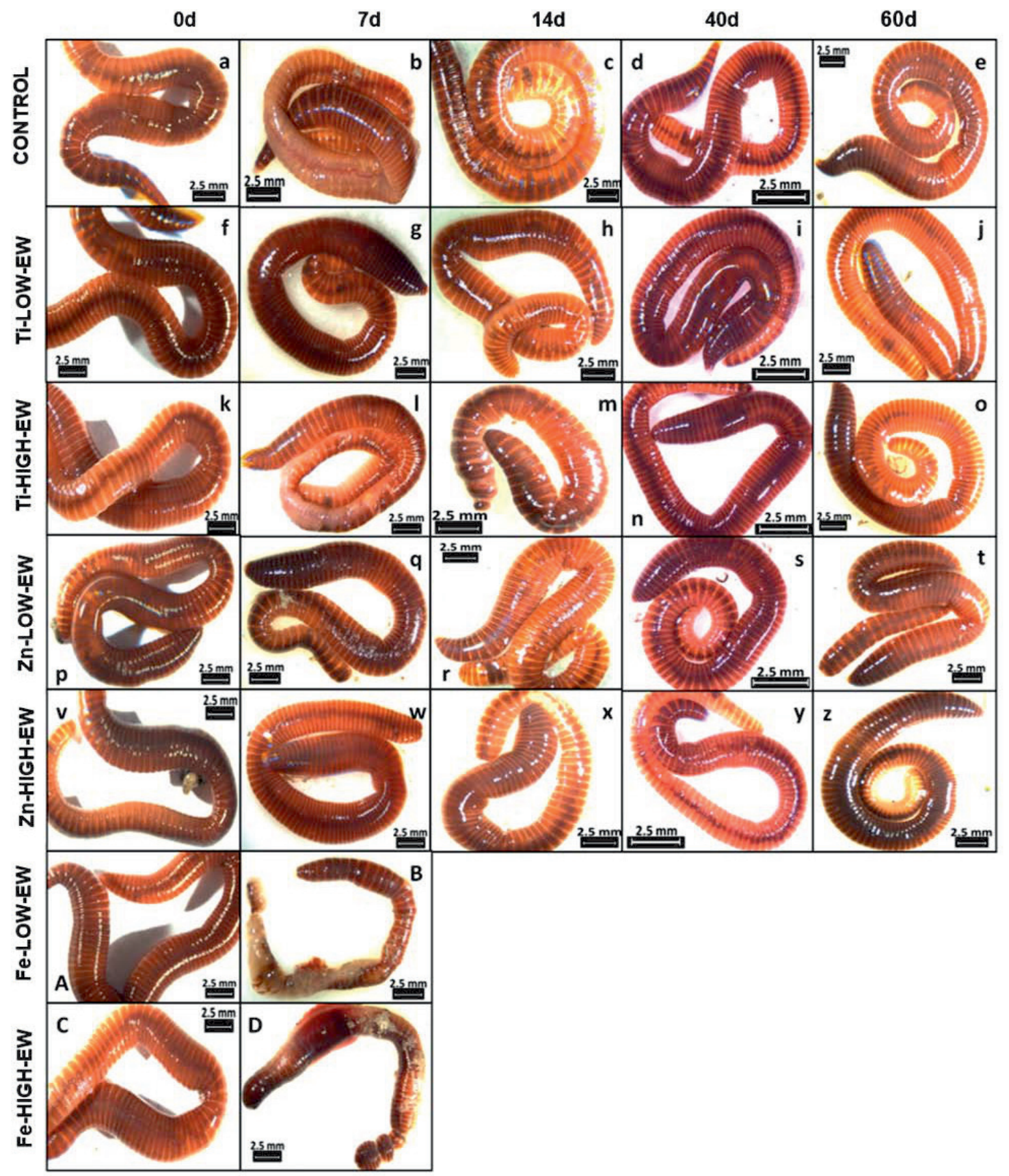

Fig. 3. Physical damage of earthworm (Eisenia fetida) caused by high and low doses of hematite $\left(\alpha-\mathrm{Fe}_{2} \mathrm{O}_{3}\right)$, zinc oxide ( $\left.\mathrm{ZnO}\right)$, or titanium dioxide $\left(\mathrm{TiO}_{2}\right)$ nanoparticles. Earthworms were fed with vermicompost and grew in an agricultural soil under growth chamber conditions for 60 days. Destructive samplings were carried out at $0,7,14,40$, and 60 days after the onset of the experiment. Treatment description can be found in Table 3 .

$0.3 \mathrm{~g}$ ZnO-NPs kg dry soil compared to the CONTROL treatment (Fig. 4f).

\section{Chemical Analyses}

$\mathrm{Fe}, \mathrm{Zn}$ and $\mathrm{Ti}$ concentrations in soil (Fig. 5) and earthworms (Fig. 6) were measured by ICP-AES. The soil-Fe concentration did not increase significantly $(\mathrm{P}<0.05)$ when soil was spiked with $\mathrm{Fe}_{2} \mathrm{O}_{3^{-}}, \mathrm{ZnO}-$ or $\mathrm{TiO}_{2}$-NPs and amended or not with earthworms, compared with the CONTROL treatment (Fig. 5a). Zn or Ti concentrations increased significantly when soil was spiked with $\mathrm{ZnO}$ - or $\mathrm{TiO}_{2}-\mathrm{NPs}$, with or without earthworms (Figs $5 \mathrm{~b}$ and $5 \mathrm{c}$ ).

Earthworms grown in soil spiked at high or low FeNPs doses decreased significantly the Fe concentration in earthworm tissue compared with the other treatments (Fig. 6a). Zn bioaccumulation by earthworms (Fig. 6b) 

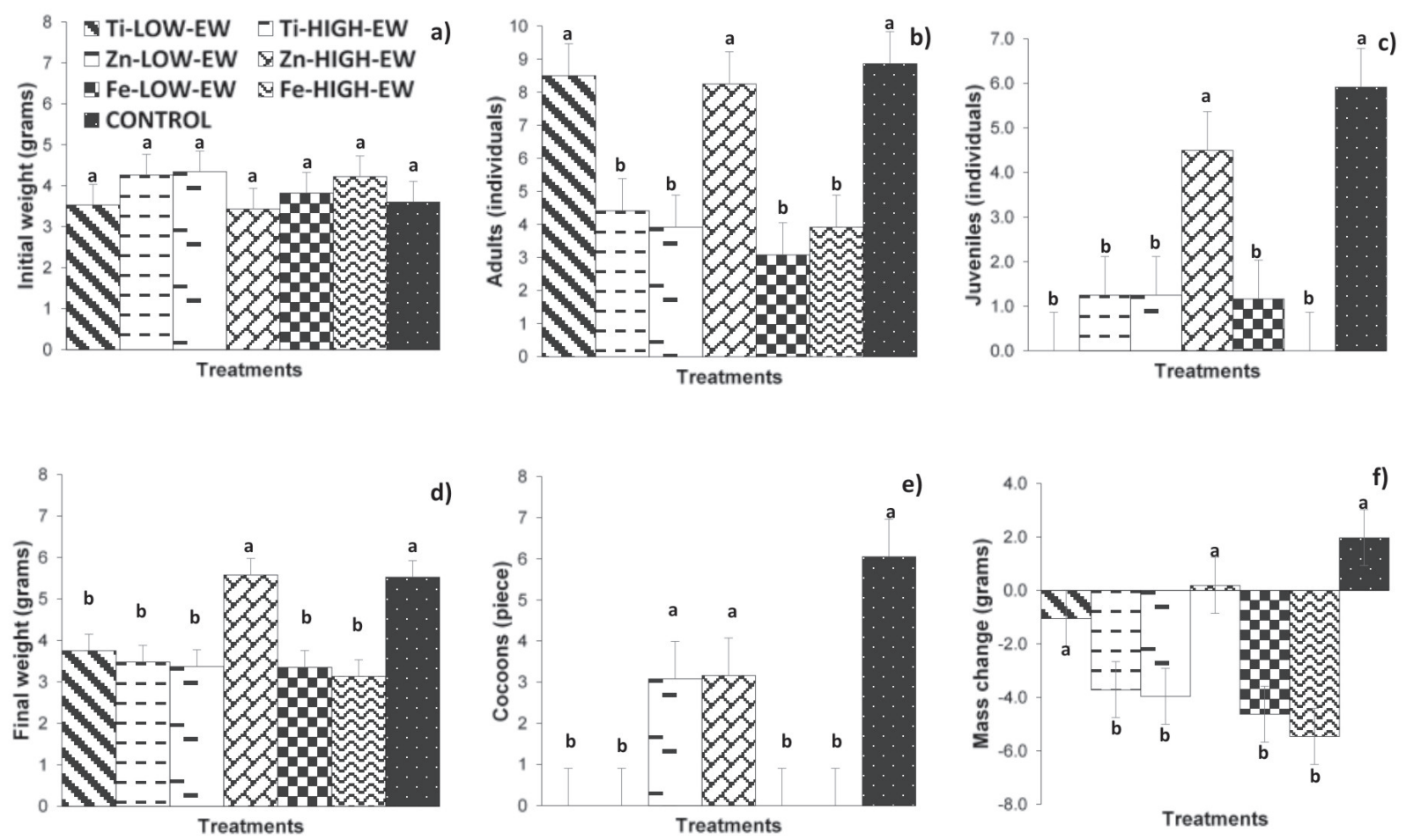

Fig. 4. Effects of hematite $\left(\alpha-\mathrm{Fe}_{2} \mathrm{O}_{3}\right)$, zinc oxide $(\mathrm{ZnO})$, or titanium dioxide $\left(\mathrm{TiO}_{2}\right)$ nanoparticles spiked on agricultural soil, on initial weight a); adults b); juveniles c); final weight d); cocoons e); and mass change f) of earthworms. Bars with the same letters are not significantly different in the figures. Treatment descriptions can be found in Table 3.

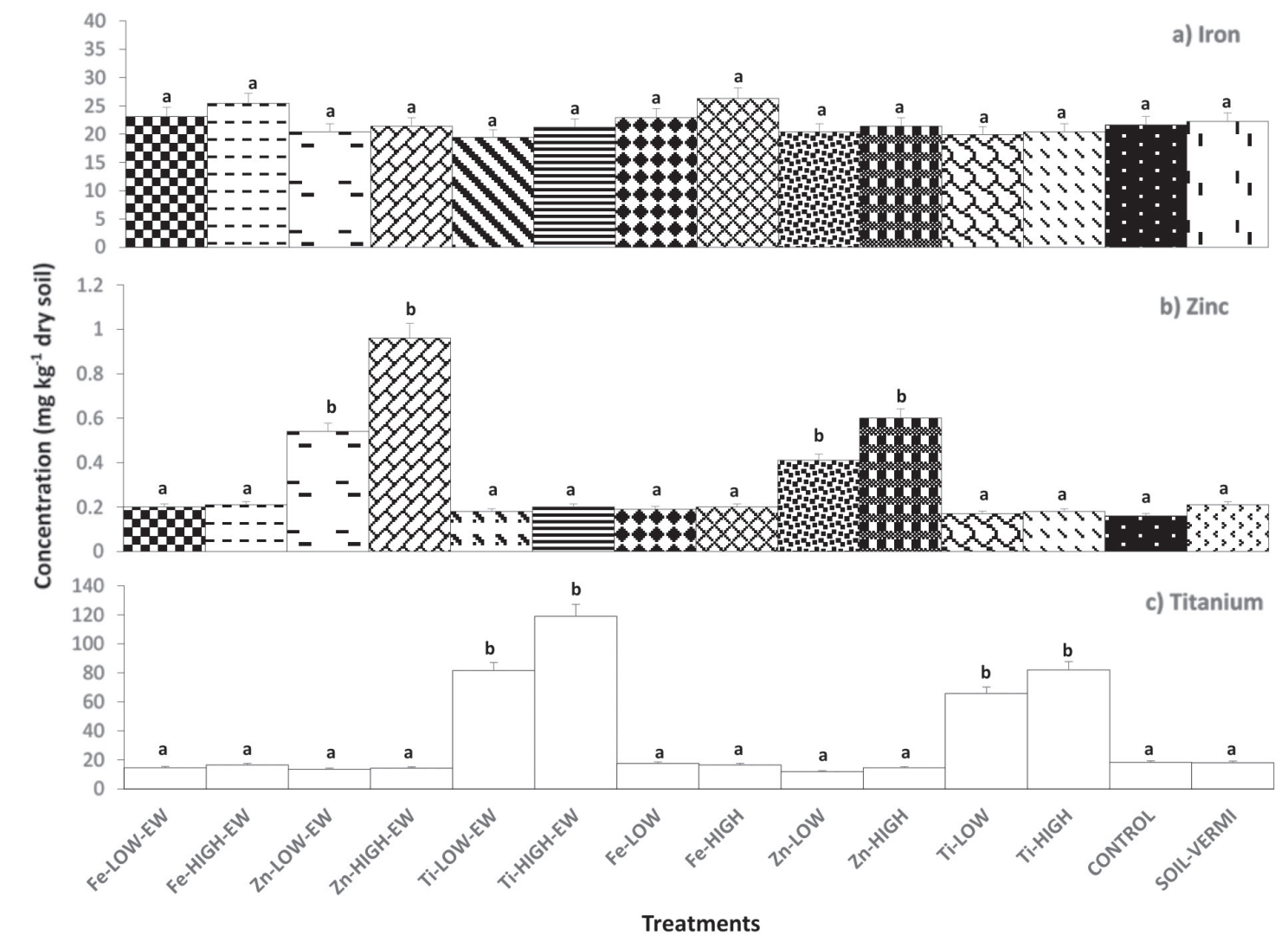

Fig. 5. Iron a), zinc b), and titanium c) concentrations in soil spiked or not with hematite $\left(\alpha-\mathrm{Fe}_{2} \mathrm{O}_{3}\right)$, zinc oxide (ZnO), or titanium dioxide $\left(\mathrm{TiO}_{2}\right)$ nanoparticles. Bars with the same letters are not significantly different in the figures. Treatment descriptions can be found in Table 3. 


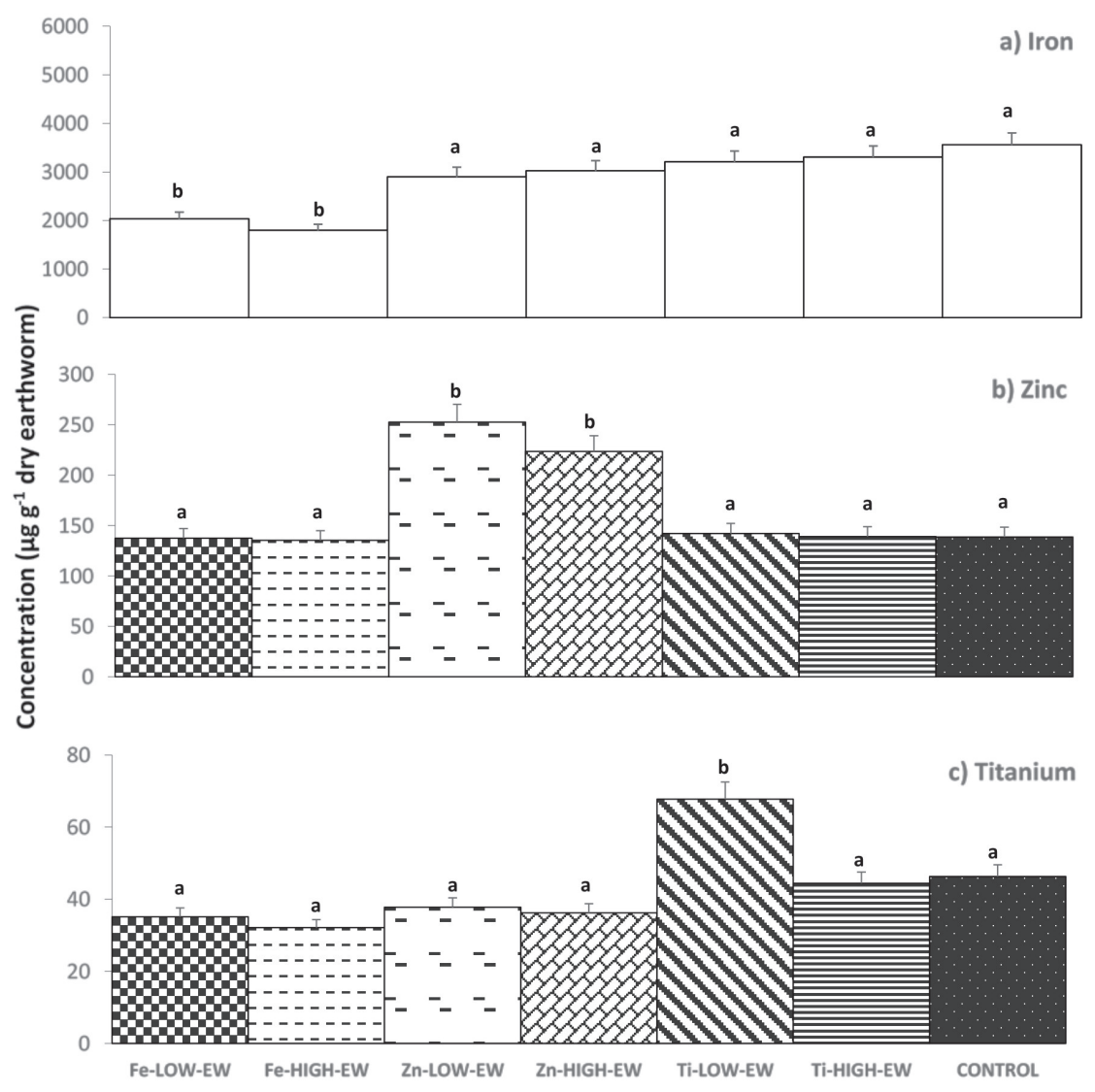

Fig. 6. Iron a), zinc b), and titanium c) concentration in earthworm tissue from Eisenia fetida grown in soil treated or not with hematite $\left(\alpha-\mathrm{Fe}_{2} \mathrm{O}_{3}\right)$, zinc oxide $(\mathrm{ZnO})$, or titanium dioxide $\left(\mathrm{TiO}_{2}\right)$ nanoparticles. Bars with the same letters are not significantly different in the figures. Treatment descriptions can be found in Table 3 .

and low concentrations of $\mathrm{ZnO}-\mathrm{NPs}$, i.e., at 0.15 and $0.3 \mathrm{~g}$ NPs kg dry soil ${ }^{-1}$ compared to the control treatment. Titanium bioaccumulation by earthworms (Fig. 6c) increased significantly when soils were amended at low concentrations of $\mathrm{TiO}_{2}-\mathrm{NPs}$, i.e., at $0.15 \mathrm{~g}$ NPs kg dry soil $^{-1}$.

\section{Discussion}

$\mathrm{Fe}_{2} \mathrm{O}_{3}-\mathrm{NPs}$ at both concentrations $(0.15$ and $0.3 \mathrm{~g}$ NPs kg dry soil ${ }^{-1}$ ) were shown to be harmful to earthworms, as witnessed by the visible physical damage to earthworms, i.e., the inflammatory reactions (Figs 3b, 3d), which could be pieces of evidence of perturbations of antioxidant enzyme activities. Liang et al. [19] studied the acute and subacute toxicity of different levels $\left(100,500,1000 \mathrm{mg} \mathrm{kg}^{-1}\right.$ dry natural soil) of nanoscale zerovalent iron on E. fetida. They found that nanoscale zerovalent iron at 500 and $1000 \mathrm{mg} \mathrm{kg}^{-1}$ perturbed the antioxidant enzyme activities (superoxide dismutase and catalase), malondialdehyde content, and reactive oxygen species (ROS). In addition, histopathological examination of transverse sections of E. fetida exposed to nanoscale zerovalent iron illustrated that there was a serious injury to epidermal tissue after exposure of 28 days [19]. Diverse effects of combined decabromodiphenyl ether and nanoscale zerovalent iron on E. fetida were also evaluated [20]. About that, it was shown that nanoscale zerovalent iron could influence the bioaccumulation and transformation of decabromodiphenyl ether, the avoidance behavior, growth, and respiration, but also superoxide dismutase, catalase, and malondialdehyde were also affected. It has to be remembered that biochemical parameters are early alarms before sublethal effects appearance. The impacts of chemically synthesized magnetite nanoparticles on earthworm Eudrilus eugeniae has also been studied at different concentrations (100, 200, and $400 \mathrm{ng} 10 \mathrm{ml}^{-1}$ de-ionized water) [21]. Samrot et al. [21] found that the impact caused by nanoparticle exposure on Eudrilus eugeniae was found to be proportionate to the nanoparticle concentration $(100,200$, and 400 ng $10 \mathrm{ml}^{-1}$ de-ionized water). They reported that the earthworm skin colour changed from brown to black with an increase in the nanoparticle concentration. In addition, they stated that histological studies revealed the impact of nanoparticle exposure on the erosion of the epithelium, fibrosis of the circular muscle and also disintegration of the gut [21]. 
In addition, in this laboratory experiment we observed that in a natural soil matrix, the three NPs evaluated ( $\mathrm{ZnO}-, \mathrm{TiO}_{2}-$, or $\left.\mathrm{Fe}_{2} \mathrm{O}_{3}-\mathrm{NPs}\right)$ had significant effects on at least one earthworm characteristic: the number of adults, number of juveniles, mortality, final weight, number of cocoons, and mass change (Figs 4b, 4c, 4d, 4e, and 4f). Similar results were reported by Lahive et al. [22] when they tested the effects of $\mathrm{ZnO}, \mathrm{Ag}$ and $\mathrm{TiO}_{2}$ nanoparticles on the reproduction of E. fetida, and by Alandadi et al. [23] when they studied the absorption, accumulation, and reproduction of $E$. fetida treated with four levels ( 0 , $0.4,0.8$, and $1.2 \mathrm{~g} \mathrm{~kg}^{-1}$ substrate) of $\mathrm{ZnO}$ - or CuO-NPs. In addition, survival, weight change, and reproduction of $E$. andrei were affected by both $\mathrm{Zn}$ forms ( $\mathrm{ZnO}-\mathrm{NP}$ or $\mathrm{Zn}^{2+}$ ions) according to studies by Romero-Freire et al. [7].

In the case of $\mathrm{ZnO}-\mathrm{NPs}$, we observed that the more harmful concentration of NPs to earthworms was $0.15 \mathrm{~g}$ NPs kg dry soil ${ }^{-1}$, since it was the concentration that caused loss of body mass and provided a higher mortality in relation to the other concentration of $\mathrm{ZnO}-\mathrm{NPs}$. Similar results have been reported in a test to assess the toxicity of ZnO-NPs in E. fetida earthworms, in which filter paper was used and it was shown that the mortality of earthworms was higher at lower concentrations $\left(50 \mathrm{mg} \mathrm{ZnO} \mathrm{L^{-1 }}\right.$ ) and appeared to decrease with higher levels of concentration [19]. In addition, a small increase in the activities of superoxide dismutase in the lowest exposure of $\mathrm{ZnO}$ (50 $\mathrm{mg} \mathrm{kg}^{-1}$ ) was observed and there was a decrease at $100 \mathrm{mg} \mathrm{kg}^{-1}[19,24]$. Also, it could be related to the phenomenon of death and major damage in earthworms at lower concentrations. Likewise, in another study to evaluate the toxicity of $\mathrm{ZnO}-\mathrm{NPs}$ to E. fetida earthworms in soil; the results showed that catalase had an increase in very low doses $\left(0.1\right.$ and $0.5 \mathrm{~g} \mathrm{~kg}^{-}$ $\left.{ }^{1}\right)$; however, catalase activity was decreased at higher doses. In the case of malondialdehyde, it increased markedly within the first three doses $(0.1,0.5$ and $1 \mathrm{~g}$ $\left.\mathrm{kg}^{-1}\right)$ and decreased at the highest dose $\left(5 \mathrm{~g} \mathrm{~kg}^{-1}\right)$. The superoxide dismutase activity showed a tendency to decrease and was significantly lower than the control when the dose of $\mathrm{ZnO}$ NPs was greater than $0.5 \mathrm{~g} \mathrm{~kg}^{-1}$ $[19,24,25]$. In the case of malondialdehyde, as a biomarker for oxidative stress it increased in small doses, indicating that in small doses oxidative stress occurs.

Related to bioaccumulation, our results show that $\mathrm{Zn}$ levels increased along with increasing NP doses, and similar results were obtained in recent studies with earthworms [24, 25]. ZnO-NPs were also found to be bioavailable and can cause toxicity to E. fetida earthworms [26]. In addition, Nadiri et al. [27] exposed to E. fetida to $0,2.5,5,10,20$ and $40 \mathrm{~g} \mathrm{~kg}^{-1}$ of nano$\mathrm{ZnO}$ and $\mathrm{ZnO}$ for 28 days. They found similar results when stated that E. fetida could absorb nanoparticles just like the zinc heavy metal, so that increasing the concentration of $\mathrm{ZnO}$ and nano- $\mathrm{ZnO}$ in soil while their accumulation rate was increased in the earthworm tissue as well (Figs 5, 6).

In the case of $\mathrm{TiO}_{2}-\mathrm{NPs}$, at each sampling day a decrease in body mass (final weight) was seen, although there were no deaths or apparent physical damage. The results were corroborated by statistical analysis, which showed significant differences related to the mass change at $0.3 \mathrm{~g} \mathrm{TiO}_{2}-\mathrm{NPs} \mathrm{kg}$ dry soil ${ }^{-1}$ compared to the control treatment. Lapied et al. [28] found that Lumbricus terrestris exposed to $\mathrm{TiO}_{2}$ nanocomposites at concentrations ranging from 0 to $100 \mathrm{mg} \mathrm{kg}^{-1}$ showed no mortality, but an enhanced apoptotic frequency was higher in the cuticule, intestinal epithelium and chloragogenous tissue than in the longitudinal and circular musculature, which might explain the loss of weight of earthworms. Earthworms amended with $\mathrm{TiO}_{2}$ - and $\mathrm{Fe}_{2} \mathrm{O}_{3}$-NPs presented significant differences in reproduction (juveniles and cocoons) compared to the CONTROL treatment, while $\mathrm{TiO}_{2}-\mathrm{NPs}$ at $0.15 \mathrm{~g} \mathrm{~kg}$ dry soil ${ }^{-1}$ did not lead to adult deaths (Fig. 4). Similarly, the results in a study to assess the behavior and reproduction of earthworms exposed to nanoparticulate titanium dioxide in soil indicate that the earthworms can detect $\mathrm{TiO}_{2}$-NPs present in the soil. However, exposure had no apparent effects on survival or reproduction standard parameters [29].

Corroborating the data statistically obtained, a study showed that $\mathrm{TiO}_{2}-$ and $\mathrm{ZnO}-\mathrm{NPs}$ exhibited no acute toxicity to earthworms [30]. However, as witnessed by our results, biochemical alterations and physical changes were early alarms before the appearance of acute and sublethal effects. Finally, regarding the worms, there are studies which have shown that although no effects on reproduction or survival occur, the damage occurs at the cellular level, so the effects could be seen over the longer term [31].

\section{Conclusions}

The $\mathrm{Fe}_{2} \mathrm{O}_{3}$-NPs cause obvious physical damage to Eisenia fetida. However, untreated worms and those exposed to $\mathrm{TiO}_{2}-$ and $\mathrm{ZnO}-\mathrm{NPs}$ are grown without evident damage to the earthworm body. The $\mathrm{Fe}_{2} \mathrm{O}_{3}-\mathrm{NPs}$ significantly decreased the survival of earthworms, while $\mathrm{TiO}_{2}$ - and $\mathrm{Fe}_{2} \mathrm{O}_{3}$-NPs significantly decreased earthworm reproduction (the number of young and number of cocoons) compared to ZnO-NPs. The growth, development and survival of earthworms are altered when placed in contact with different doses or types of NPs, so it is necessary to develop further field and laboratory research for assessing ecological and environmental damage caused by the use and release of NPs. In addition, these findings will provide a comprehensive understanding of toxicological effects of $\mathrm{Fe}_{2} \mathrm{O}_{3}-, \mathrm{TiO}_{2}-$ and $\mathrm{ZnO}-\mathrm{NPs}$ in E. fetida grown in an agricultural soil amended with vermicompost. 


\section{Acknowledgements}

We thank Ireneo García Ortíz and Luis Hernández for technical assistance. The work was funded by Ciencia Básica SEP-CONACyT projects 151881 and 287225, CONACyT-SINANOTOX PN-2017-01-4710, and by the Sustainability of Natural Resources and Energy Program (Cinvestav-Saltillo). MF V-R received grantaided support from Ciencia Básica SEP-CONACyT. LI T-T, and F F-L received grant-aided support from Sistema Nacional de Investigadores-CONACyT, Mexico.

\section{Conflict of Interest}

The authors declare no conflict of interest.

\section{References}

1. LEON-SILVA S., FERNÁNDEZ-LUQUEÑO F., LOPEZ-VALDEZ F. Silver nanoparticles (AgNP) in the environment: a review of potential risks on human and environmental health. Water Air and Soil Pollution, 227, $1,2016$.

2. RIZWAN M., ALI S., QAYYUM M.F, OK Y.S., ADREES M., IBRAHIM M., ZIA-UR-REHMAND M., FARID M., ABBAS F. Effect of metal and metal oxide nanoparticles on growth and physiology of globally important food crops: A critical review. Journal of Hazardous Materials, 322, 2, 2017.

3. JOKAR M., PEDERSEN G.A., LOESCHNER K. Six open questions about the migration of engineered nano-objects from polymer-based food-contact materials: a review. Food Additives and Contaminants Part A-Chemistry Analysis Control Exposure \& Risk Assessment, 34, 434, 2017.

4. SADEGHI R., RODRIGUEZ R.J., YAO Y., KOKINI JL. Advances in nanotechnology as they pertain to food and agriculture: benefits and risks. Annual Review of Food Science and Technology, 8, 467, 2017.

5. STEWART D.T.R., NOGUERA-OVIEDO K., LEE V., BANERJEE S., WATSON D.F., AGA D.S. Quantum dots exhibit less bioaccumulation than free cadmium and selenium in the earthworm Eisenia andrei. Environmental Toxicology and Chemistry. 32, 1288, 2013.

6. KWAK J.I., AN Y.J. The current state of the art in research on engineered nanomaterials and terrestrial environments: Different-scale approaches. Environmental Research, 151, 368, 2016.

7. ROMERO-FREIRE A., LOFTS S., PEINADO F.J.M., VAN GESTEL C.A.M. Effects of aging and soil properties on zinc oxide nanoparticle availability and its ecotoxicological effects to the earthworm Eisenia andrei. Environmental Toxicology and Chemistry, 36, 137, 2017.

8. FERNÁNDEZ-LUQUEÑO F., LOPEZ-VALDEZ F., SARABIA-CASTILLO C.R., GARCÍA-MAYAGOITIA S., PEREZ-RIOS S.R. Bioremediation of polycyclic aromatic hydrocarbons-polluted soils at laboratory and field scale: a review of the literature on plants and microorganisms. In: Enhancing cleanup of environmental pollutants Vol. 1: Biological approaches, ANJUM N.A.,
GILL S.S., TUTEJA N. (Eds.), Springer. Switzerland, 43-64, 2017.

9. FERNÁNDEZ-LUQUEÑO F., LOPEZ-VALDEZ F., PÉREZ-MORALES C., GARCÍA-MAYAGOITIA S., SARABIA-CASTILLO C.R., PEREZ-RIOS S.R. Enhancing decontamination of PAHs-polluted soils: role of organic and mineral amendments. In: Enhancing cleanup of environmental pollutants Vol. 2: Non-biological approaches, ANJUM N.A., GILL S.S., TUTEJA N. (Eds.), Springer. Switzerland, 339, 2017.

10. SWIATEK Z.M., VAN GESTEL C.A.M., BEDNARSKA A.J. Toxicokinetics of zinc-oxide nanoparticles and zinc ions in the earthworm Eisenia andrei. Ecotoxicology and Environmental Safety, 143, 151, 2017.

11. HRDA K., OPRSAL J, KNOTEK P, POUZAR M., VICEK M. Toxicity of zinc oxide nanoparticles to the annelid Enchytraeus crypticus in agar-based exposure media. Chemical Papers, 70, 1512, 2016.

12. GARCIA-GOMEZ C., BABIN M., OBRADOR A., ALVAREZ J.M., FERNANDEZ M.D. Toxicity of $\mathrm{ZnO}$ nanoparticles, $\mathrm{ZnO}$ bulk, and $\mathrm{ZnCl}_{2}$ on earthworms in a spiked natural soil and toxicological effects of leachates on aquatic organisms. Archives of Environmental Contamination and Toxicity, 67, 465, 2014.

13. YAUSHEVA E., SIZOVA E., LEBEDEV S., SKALNY A., MIROSHNIKOV S., PLOTNIKOV A., KHLOPKO Y., GOGOLEVA N., CHERKASOV S. Influence of zinc nanoparticles on survival of worms Eisenia fetida and taxonomic diversity of the gut microflora. Environmental Science and Pollution Research, 23, 13245, 2016.

14. OECD. OECD guidelines for the testing of chemicals/ section 2: Effects on biotic systems test no. 207: Earthworm, acute toxicity tests, Organization for Economic Cooperation and Development. París, Francia. 1984.

15. WSDE. Earthworm bioassay protocol for soil toxicity screening. Deparment of Ecology. Washington. USA. 1996.

16. ETCC. Biologycal Test Method: Test for Toxicity of Contaminated Soil to Earthworms: (Eisenia andrei, Eisenia fetida or Lombricus terrestris). Environment Canada. Ontario, Canada. 2007.

17. FERNÁNDEZ-LUQUEÑO F., GAMERO-MELO P., LÓPEZ-VALDEZ F., AGUILERA.GONZÁLEZ E.N., GARCÍA-GUILLERMO M.S., HERNÁNDEZMARTÍNEZ G., FERNÁNDEZ-FERNÁNDEZ O., ALVAREZ-GARZA, M.A., PÉREZ-VELÁZQUEZ I.R. Physicochemical and microbiological characterization for drinking water quality assessment in Southeast Ciahuila, Mexico. International journal of Environment and Pollution, 59 (1), 78, 2016.

18. PAMPILLÓN-GONZÁLEZ L., LUNA-GUIDO M., RUÍZ-VALDIVIEZO V.M., FRANCO-HERNÁNDEZ O., FERNÁNDEZ-LUQUEÑO F., PAREDES-LÓPEZ O., HERNÁNDEZ G., DENDOOVEN L. Greenhouse gas emission and growth of wheat cultivated in soil amended with digestate from biogas production. Pedosphere, 27 (2), 318, 2017.

19. LIANG J., XIA X.Q., ZHANG W., ZAMAN W.Q., LIN K.F., HU S.Q., LIN Z.F. The biochemical and toxicological responses of earthworm (Eisenia fetida) following exposure to nanoscale zerovalent iron in a soil system. Environmental Science and Pollution Research, 24 (3), 2507, 2017. 
20. LIANG J., XIA X.Q., ZAMAN W.Q., ZHANG W., LIN K.F., HU S.Q., LIN Z.F. Bioaccumulation and toxic effects of decabromodiphenyl ether in the presence of nanoscale zero-valent iron in an earthworm soil system. Chemosphere, 169, 78, 2017.

21. SAMROT A.V., JUSTIN C., PADMANABAN S., BURMAN. A study on the effect of chemically synthesized magnetite nanoparticles on earthworm: Eudrilus eugeniae. Applied Nanoscience, 7 (1-2), 17, 2017.

22. LAHIVE E., MATZKE M., DURENKAMP M., LAWLOR A.J., TACHER S.A., PEREIRA M.G., SPURGEON D.J., UNRINE J.M., SVENDSEN C., LOFTS S. Sewage sludge treated with metal nanomaterials inhibits earthworm reproduction more strongly than sludge treated with metal metals in bulk/salt forms. Environmental Science-Nano, 4 (1), 78, 2017.

23. ALANDADI I., BEHBOUDI F. The effects of $\mathrm{CuO}$ and $\mathrm{ZnO}$ nanoparticles on survival, reproduction, absorption, overweight, and accumulation in Eisenia fetida earthworm tissues in two substrates. International Journal of Environmental Research, 9 (1), 35, 2015.

24. LI L.Z., ZHOU D.M., PEIJNENBURG W.J.G.M., GESTEL C.A.M., JIN S.Y., WANG Y.J., WANG P. Toxicity of zinc oxide nanoparticles in the earthworm, Eisenia fetida and subcellular fraction of Zn. Environment International. 37, 1098, 2011.

25. HU C.W., LI, M., CUI Y.B., LI D.S., CHEN J., YANG L.Y. Toxicological effects of $\mathrm{TiO}_{2}$ an $\mathrm{ZnO}$ nanoparticles in soil on earthworm Eisenia fetida. Soil Biology and Biochemistry, 42, 586, 2010.
26. MA H.B., WILLIAMS P.L. DIAMOND S.A. Ecotoxicity of manufactured $\mathrm{ZnO}$ nanoparticles - A review. Environmental Pollution, 172, 76, 2013.

27. NADIRI S., OMRANI G., AGHA M.M.A., EMTYAZJOO M., ZAKERI H. Comparing LC50 and bioaccumulation rate of nano zinc oxide and zinc oxide by Eisenia fetida in vermicompost. Research Journal of Biotechnology, 10 (5), 1, 2015.

28. LAPIED E., NAHMANI J.Y., MOUDILOU E., CHAURAND P., LABILLE J., ROSE J., EXBRAYAT J.M., OUGHTON D.H., JONER E.J. Ecotoxicological effects of an aged $\mathrm{TiO}_{2}$ nanocomposite measured as apoptosis in the anecic earthworm Lumbricus terrestris after exposure through water, food and soil. Environment International, 37 (6), 1105, 2011.

29. McSHANE H., SARRAZIN M., WHALEN J.K., HENDERSHOT W.H., SUNAHARA G.I. Reproductive and behavioral responses of earthworms exposed to nanosized titanium dioxide in soil. Environment Toxicololy and Chemistry. 31, 184, 2012.

30. CANAS J.E., QI B.B., LI S.B., MAUL J.D., COX S.B., DAS S., GREEN M.J. Acute and reproductive toxicity of nano-sized metal oxides $\left(\mathrm{ZnO}\right.$ and $\left.\mathrm{TiO}_{2}\right)$ to earthworms (Eisenia fetida), Journal of Environmental Monitoring 13, 3351, 2011.

31. WHITFIELD M.L.W., McSHANE H., SIMPSON M.J, SIMPSON A.J., WHALEN J.K., HENDERSHOT W.H., SUNAHARA G.I. Earthworm sublethal responses to titanium dioxide nanomaterial in soil detected by H-1 NMR Metabolomics. Environmental Science and Technology 46, 1111, 2012. 